\title{
SEVEN SWORDS OF THE RENAISSANCE FROM AN ANALYTICAL POINT OF VIEW
}

BY

A. R. WILLIAMS

IN an earlier paper in Gladius, I discussed methods of producing hardened steel sword blades in the Middle Ages; most of the specimens illustrated came from the period 1000-1500 A. D. ${ }^{1}$

Comparatively little has been written about Greek and Roman sword blades ${ }^{2}$ but a good deal about the pattern-welding of those blades which succeeded them in Western Europe. ${ }^{3}$ This was a method (practised between the $3 \mathrm{rd}$ and 10 th centuries A.D.) of making large sword blades out of numerous small pieces of iron, producing, in addition, a decorative effect which was much prized, at least as much as any improvement in hardness. With the revival of the employment of large shaft furnaces, ${ }^{4}$ larger pieces of iron could be made, and pattern-welded blades went out of use around the 10 th/ $/ 11$ th century. Many blades of the Middle Ages were simply made by forging out a single bar of iron, edge-carburising it and then hardening the steeled edge by some form of heat-treatment, of which an example is specimen. No. 1. Other blades were made by forging together layers of steel and iron to give a steel cutting-edge (on a softer core) which could then be hardened.

This is illustrated here by specimen No. 3. Yet others were made by forging out cakes of high-carbon steel, probably Indian «wootz» imported by the Vikings via Persia. ${ }^{6}$

1 Williams, A. R., «Methods of manufacture of swordblades in the Middle Ages», Gladius, XIII, p. $75 \mathrm{ff}$.

2 Panseri, C.; Garino, C., \& Leoni, M., give an analysis of a 4th century B. C. Etruscan spearhead in «Documenti e Contributi per la Storia della Metallurgia» (Milan, 1957), and Williams, A. R., «A technical note on Roman arms and armour», Journal of Arcbaeological Science, forthcoming.

3 Anstee, J. W., \& BIEK, L., "A study in pattern-welding», Medieval Arcbaeo$\log y(1958), 71$.

${ }_{4}^{4}$ Gille, B., «Le moulin à fer et le haut fourneau», Metaux et Civilisations (1945-6), 1, 89.

5 Piaskowski, J., «The manufacture of medieval damascened knives», in Journal of the Iron and Steel Institute (1954), 561. ANTEINS, A. K., «Structure and manufacturing techniques of pattern-welded objects found in the Baltic states», ibid. (1968), 563.

6 For the high-carbon steel, see the Ulfberht sword in (1). The trade in steel 
However, from the 16th century onwards, some sword blades are made by entirely different methods, which reflect contemporary methods of hardening armour.

There are two interdependent problems - first, to obtain a high enough carbon content in the requisite place, so that the cutting edges are hardenable; and secondly, to heat-treat the blade so that the optimum combination of hardness and toughness is obtained. Solutions to both these problems were slowly evolved during the Middle Ages.

First, the production of steel. While the manufacture of steel directly in the «bloomery hearth» is possible, ${ }^{7}$ this would be a difficult reaction to control, and the use of steel in welded-on edges does suggest that it remained scarce because it was relatively difficult to produce. This is reflected in its price: in England, the price per pound $(1 \mathrm{lb} .=454 \mathrm{~g}$.) of iron and steel at different periods was (in old pence, $1 \mathrm{~d}$. $=£ 0.004$ ).

\begin{tabular}{|c|c|c|}
\hline Date & Iron & Steel \\
\hline 1300 & $0.447 \mathrm{~d}$ & $1.65 \mathrm{~d}$. \\
\hline 1400 & $0.839 \mathrm{~d}$ & $1.60 \mathrm{~d}$ \\
\hline 1500 & $0.438 \mathrm{~d}$ & $1.20 \mathrm{~d}$ \\
\hline 1550 & $0.127 \mathrm{~d}$. & $2.32 \mathrm{~d}{ }^{8}$ \\
\hline
\end{tabular}

The case-carburising of an iron bar or plate would partly convert the iron to steel. If several such bars or plates were piled together and forged out, or if one was folded and forged, then a streaky, inhomogeneous steel would be obtained. An example of this is specimen No. 5. The regular spacing of the banding in this example makes it unlikely that it was merely the result of forging out a heterogeneous bloom.

If the process of piling was continued, then the carbon content will equalise throughout the bar, and eventually a homogeneous steel will result. Examples of this are specimens Nos. 2, 4, 6, 7.

from the Orient is described in ZeKI VALidi, A., «Die Schwerter der Germanen, nach arabischen Berichten des 9-11 Jh.», Z. Deutscblands Morgenlands-Gesellscbaft (1936), 90, 19.

7 Tylecote, R. F.; Austin, J. N., \& Wraith, A. E., «Mechanism of the Bloomery process in shaft furnaces», Journal of the Iron and Steel Institute (1971), 290,342 .

The «Champlain forge», a method of making steel directly continued in use in America until well into the 19th century.

Hiorns, A. H., «Iron and steel manufacture» (1889), 44.

${ }^{8}$ Rogers, T., «A history of prices and wages in England», III, 346. 
Numerous specimens of streaky steels as well as (for the best examples) homogeneous steels are to be found in armour of the later 15 th century and the latter become common in the 16th century. ${ }^{9}$

It is probable that the methods employed for making swords were transferred to the manufacture of steel armour.

Having obtained the steel, by whatever method, and having it fabricated to the desired shape, the next stage is to harden it by heat-treatment. The optimum method is generally (nowadays) to harden and temper a steel in two stages by fully quenching and then carefully reheating.

By the start of the 16 th century, successful methods of achieving this had been developed for armour. ${ }^{10}$ Similar methods were evidently in use for swordblades, for four of the specimens described here (Nos. 2, 4, 6, 7, and perhaps 3 as well) were hardened in this way.

Two of the possible reasons for these developments are, first, the threat of firearms, which made the improvement of armours' resistance to bullets necessary, and second, the growth of chemistry, as distinct from alchemy, providing a greater fund of empirical workshop knowledge.

The other specimens were hardened by other, older, means; No. 5 was slack-quenched, and No. 1 was tempered as well. These methods were employed in the Middle Ages as less efficient, but simpler, substitutes for the two-stage process 1 .

9 Henger, G. W., «Metallography of iron-base samples», Bulletin of the Historical Metallurgy Group (1970), 4, 50. This also includes the only published analysis of a Renaissance sword that I am aware of. The sword (16th cent.) was edgecarburised and quenched.

Williniss, A. R., "Problems in the analysis of armour», Institut Suisse d'Armes Anciennes: Rapport (1972/74).

10 Wixliams, A. R., "A technical study of some of the armour of King Henry VIII and his contemporaries", Archaeologia, forthcoming. 


\section{SPECIMENS}

\begin{tabular}{|c|c|c|c|c|}
\hline No. & Date & Museum & $\begin{array}{l}\text { Inventory } \\
\text { number }\end{array}$ & $V P H$ \\
\hline 1 & 16 th cent. & $\begin{array}{l}\text { Netherlands } \\
\text { Army Museum }\end{array}$ & OP 11 & 455 \\
\hline 2 & ?16th cent. & $\begin{array}{c}\text { Frankfurt } \\
\text { Historical Musem }\end{array}$ & X 5019 & - \\
\hline 3 & late 16 th cent. & $\begin{array}{l}\text { Swiss Arms * } \\
\text { \& Armour Institute }\end{array}$ & & 480 \\
\hline 4 & c. 1580 & $\begin{array}{c}\text { Graz } \\
\text { Landesmuseum }\end{array}$ & & 325 \\
\hline 5 & 16th/17th cent. & st & & 440 \\
\hline 6 & 17th cent. & $*$ & & 440 \\
\hline 7 & 18th cent. & 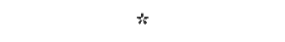 & & 470 \\
\hline
\end{tabular}

\section{ACKNOWLEDGEMENTS}

The author would like to thank Dr. Van der Sloet of the Nederlands Wapenmuseum, Leiden, Dr. Stubenvoll of the Historisches Museum, Frankfurt, Dr. Krenn of the Landeszeughaus, Graz, and Herr Eugen Heer of the Swiss Arms and Armour Institute, Grandson, for their enthusiastic co-operation. $\mathrm{He}$ would also like to express his gratitude for the help received from the British Council, the Bristish Academy, and the Austrian Institute which enabled the necessary journies to these museums to be made.

Finally, this research is supported by the Leverhulme Trust, without whose aid none of this work could have been done. 


\section{SPECIMEN NO, 1 \\ Netherlands Army Museum, Leiden \\ Inventory No. OP 11. 16 th century}

A section was removed from the edge of the blade to the centre, and examined microscopically.

The central core of the blade consists mostly of ferrite. This is surrounded by a layer of a dark-etching material, three or four times as broad as the central band.

These dark layers themselves consist of several bands, presumably of differing carbon contents, for they darken on etching to different extents, but all consisted of heat-treated steel.

The layers nearest the centre contain mostly tempered martensite. The next layers contain an irresolvable material, probably bainite, and the outer layers tempered martensite mixed with bainite, especially in the vicinity of welds (see below).

There is a good deal of slag, particularly in the centre band, running parallel to the width of the blade. There is a pale V-shaped streak following the outline of the blade surface near the edge of the ferritic band. Other streaks are to be seen in the hardened areas. These are probably the result of non-metallic inclusions incorporated during forge-welding (perhaps from a flux) which have reacted with the etchant.

Micro Hardness $=$ Max. 455

Min. $187 \mathrm{Kg} \cdot \mathrm{mm}^{-2}$

\section{ConCLusions}

This sword has been made by piling several pieces of iron and steel together and forge-welding them together.

In welding some slight decarburisation of the steel has taken place, so that quenching (after fabrication) has resulted in a mixture of microconstituents. Martensite, bainite and ? irresolvable pearlite have all been formed. Since the martensite is tempered, the hardened blade has evidently been reheated to temper it. 
POSSIBLE MANUFACTURE

IIIYIIIU

TI!Tा1)

$\longrightarrow \longrightarrow$

퍼자내
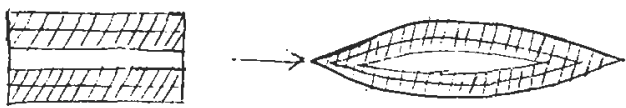

MITIETA

- IRON

WID STEEL 
Sword OP 11-X 40. Section from cutting edge to near centre of blade. $36.0,3.40$

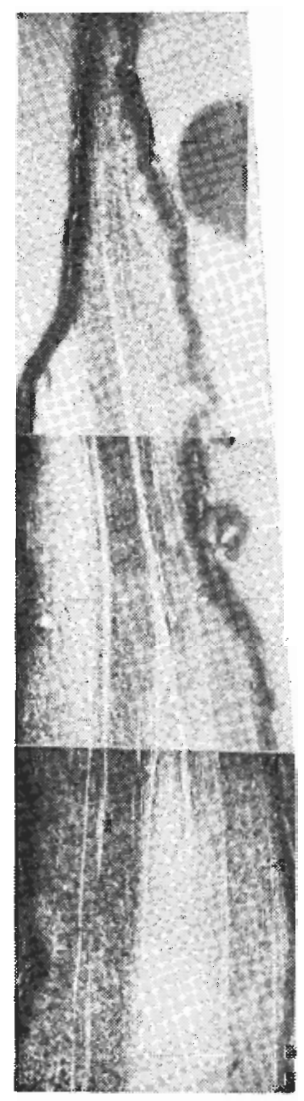


Sword OP 11. Central band X 400. 36.32a

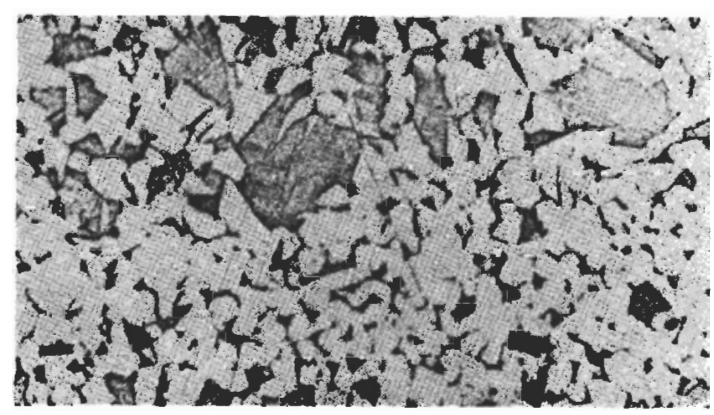

Central band nearer edge X 320.153.38a

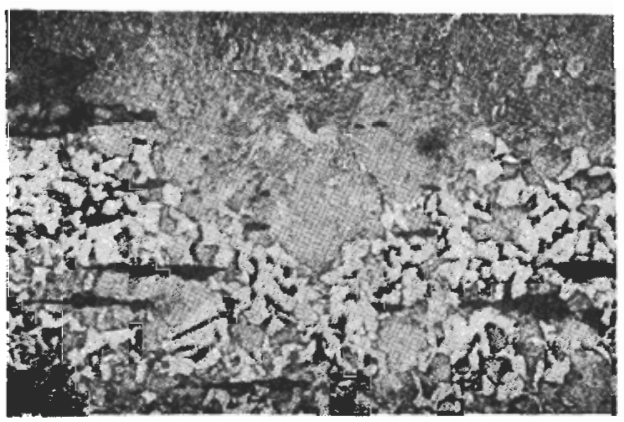

Sword OP 11-X 60. Near edge. Light streak is probably result of weld. 153.31a

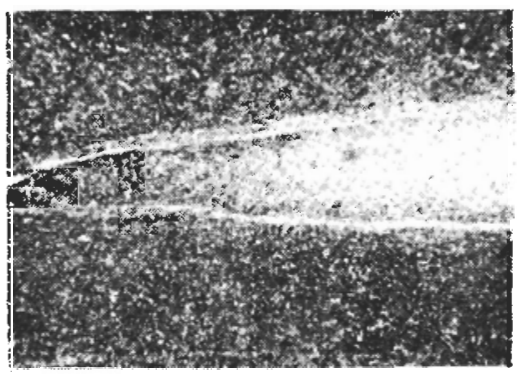


Sword OP 11-X 320. Martensite and bainite in hardened area. 153.41a

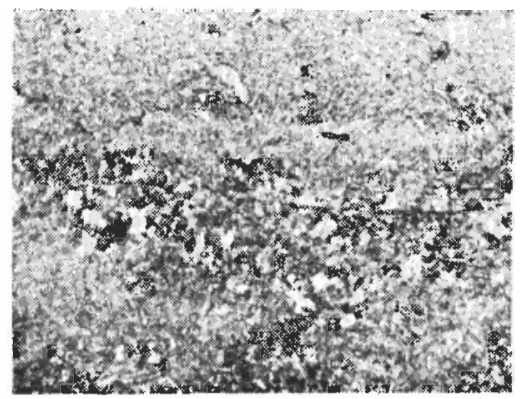

Sword OP 11-X 1280 Tempered martensite. 153.1

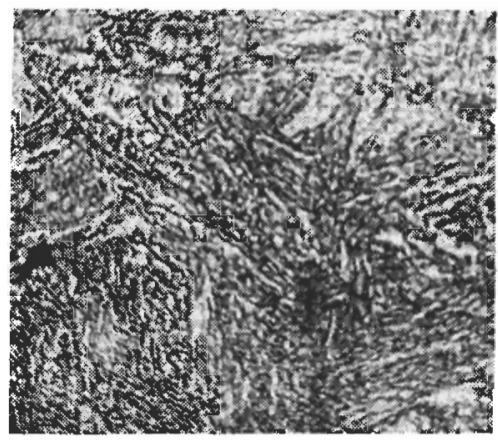


SPECIMEN NO. 2

Historical Museum, Frankfurt

Sword X 5019a. 15th or 16th century

A cross-section of this was examined, and it proved to have a very homogeneous microstructure.

At low-magnification, a large number of small slag inclusions distributed in lines parallel to the outer surfaces, show the direction of forging. The material is otherwise a remarkably uniform fine, dark-etching material. At high magnification this may be resolved as tempered martensite.

This sword has been fabricated from a homogeneous steel, which has then been hardened by heat-treatment. It has probably been quenched, i. e. rapidly cooled from above $A_{3}$ (the upper critical temperature) to transform it to martensite and then gently reheated to temper it. 
Sword X 5019. Cross-section X 20 mag. $75.4-9$
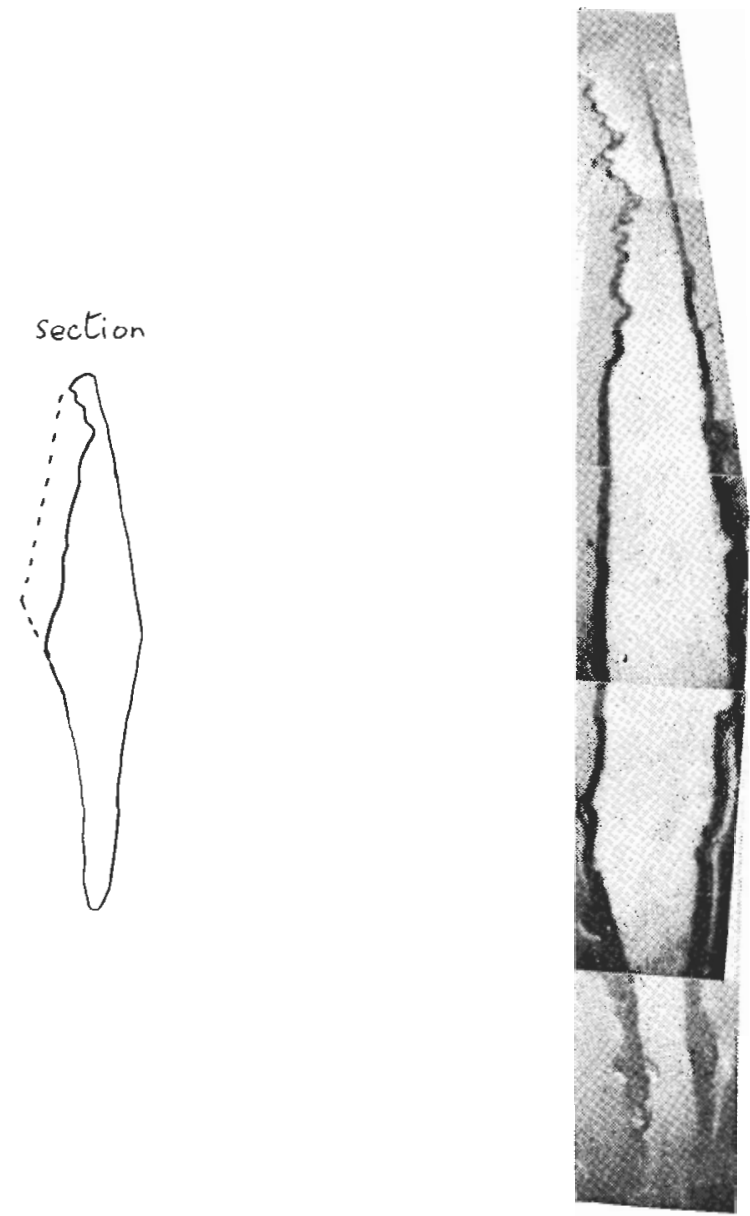
Sword X 60.75.12. X 240.75.15. The section is very uniform in composition
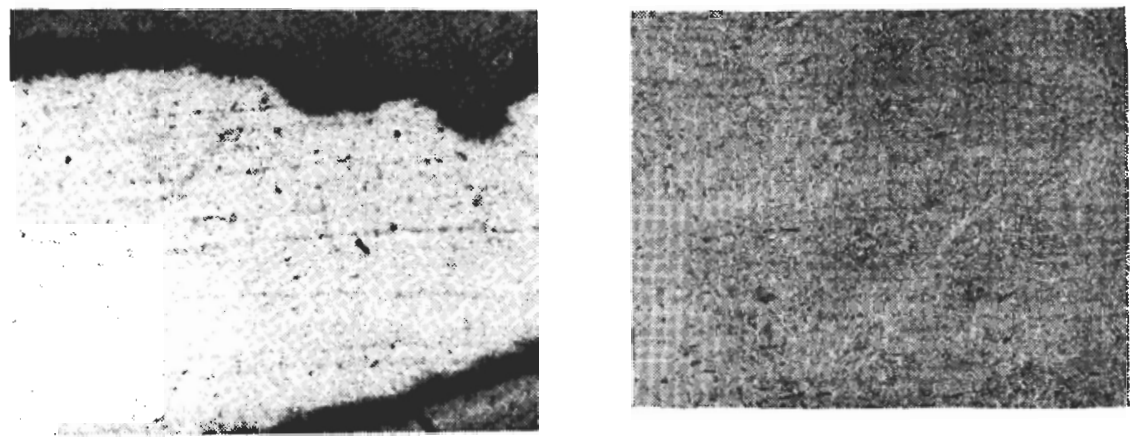

Sword X 960. Tempered martensite? Note the large slag inclusion. $75.13,14$
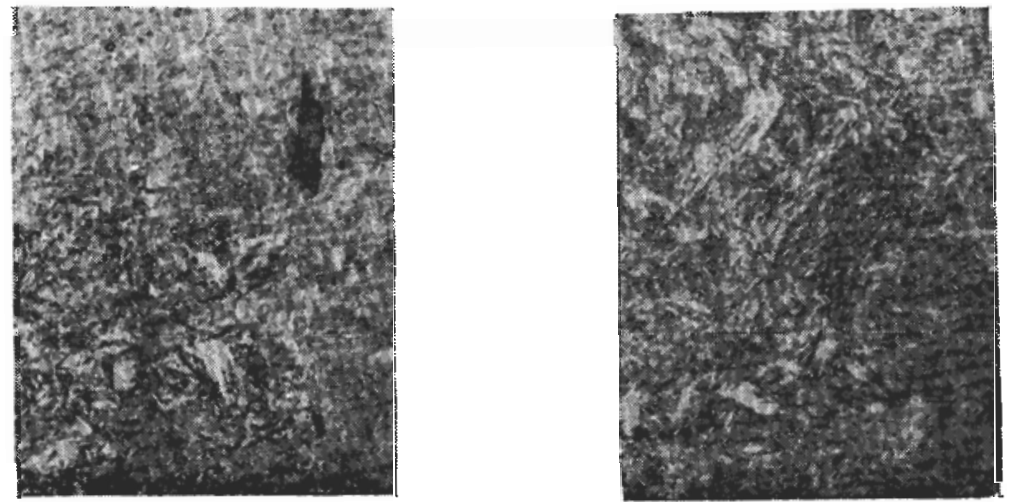


\title{
SWISS ARMS AND ARMOUR INSTITUTE
}

\author{
SwORD 3 \\ Made in South Germany, Mïnich or Solingen, late sixteenth century, \\ marked Wilbelm Wisperch on blade
}

This blade consists of a central core, which is surrounded by a surface zone of dissimilar material.

The centre consists mainly of ferrite with some slag inclusions running parallel to the width of the blade. The ferrite is mixed with increasing amounts of dark-brown-etching material as one moves away from the centre. But there is a sharp increase in the proportion of the latter, the outer surfaces of the blade and the cutting edge consisting entirely of the dark-etching component, evidently a heattreated steel.

Along the boundary between the high and low-carbon zones there is a band of pale-brown-etching material which does not coincide with any of the lines of slag inclusions in the outer zone.

The microstructure of the high-carbon zone is fairly uniform from this boundary to the edge. Except that, nearer the centre, there are some grains (equiaxed, not spiny) of ferrite. At a very high magnification, this appears to contain an irresolvable component as well as a globular one. It is assumed that the dark material is principally tempered bainite, or perhaps a tempered mixture of bainite and martensite although there are no visible traces of the lath-like structure associated with martensite.

The pale band is possibly a staining effect resulting from the absorption of some impurity during welding-the underlying structure still remains visible.

Hardness

(Core) VPH ranged from 136 to 161 . Average $=147$ ( $5 \mathrm{~kg}$ load).

(Surface) VPH ranged from 459 to 502 . Average $=481(10 \mathrm{~kg}$ load $)$.

\section{Conclusions}

This sword was made by folding a piece of steel (possibly ca. $0.5 \% \mathrm{C}$ ) around a bar of wrought iron, and welding both together. The sword was then forged out of the composite bar, some diffusion of carbon taking place across the weld. After fabrication, the sword was slack-quenched (perhaps in oil) converting the steel outer surfaces to a bainite structure or mixture of bainitic and martensitic structures. It was then slightly reheated to temper it.

This would produce a blade of inferior toughness to one of the same carbon content fully-quenched and then tempered, but it is probable that the swordsmith deliberately slack-quenched steels as it was an easier process to control than fullquenching. 
(edge)

Sword $3 \times 5$
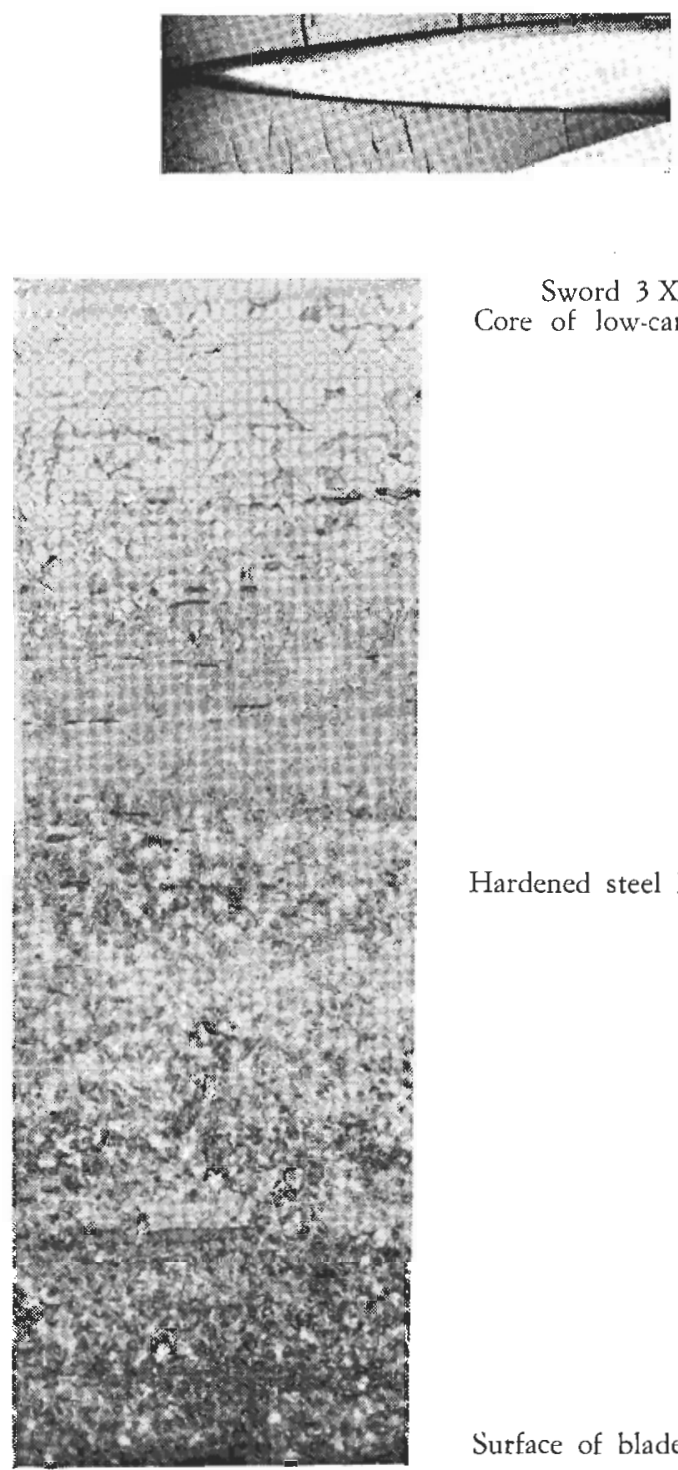

\author{
Sword $3 \times 340$ \\ Core of low-carbon iron
}

Hardened steel layer

Surface of blade 
Sword 3 X 400 . Centre: Ferrite with bainite

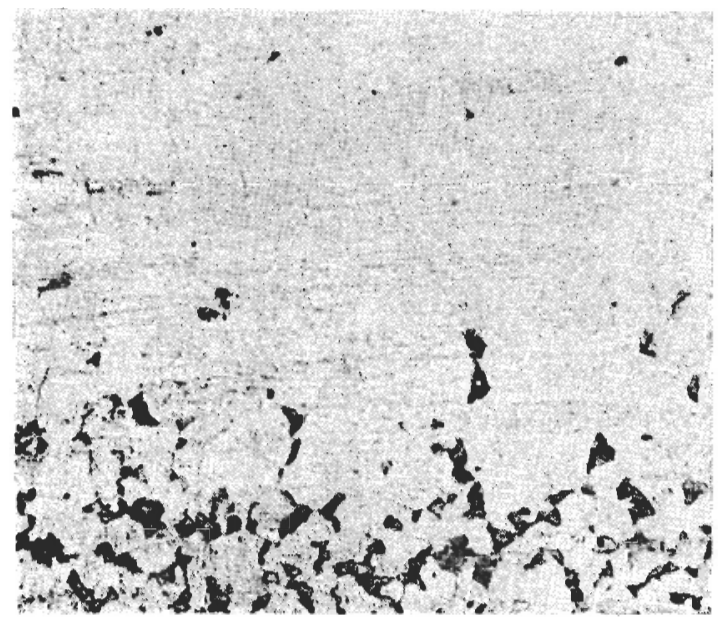

Sword 3 X 1600. Slag inclusions at the junction of the high- and low-carbon zones

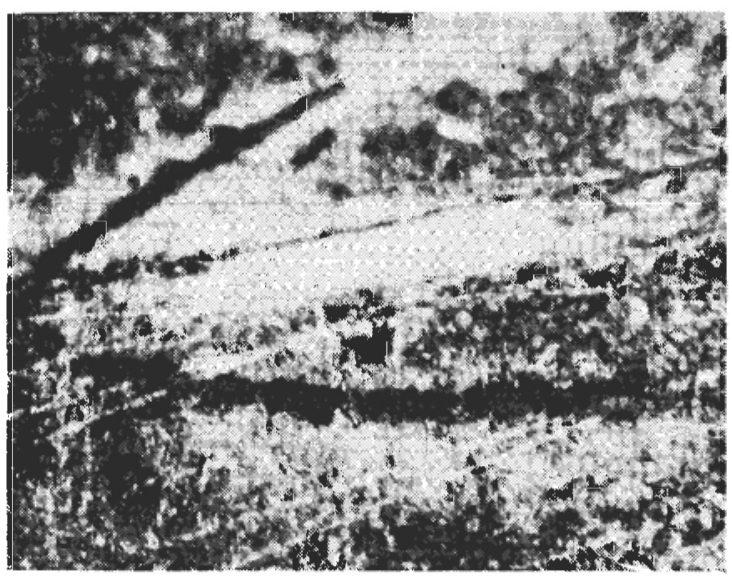


Sword 3 X 1600. The low-carbon core; ferrite and bainite

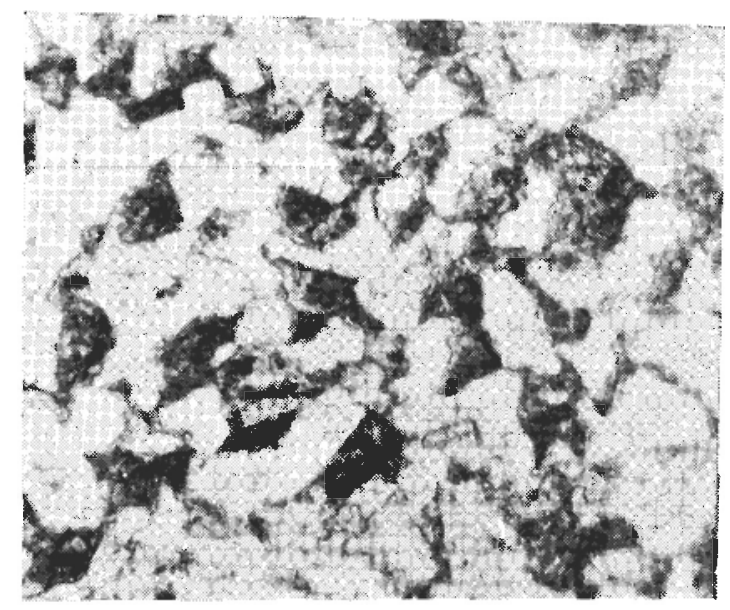

Sword 3 X 2000. Bainite and ferrite, showing light-coloured band

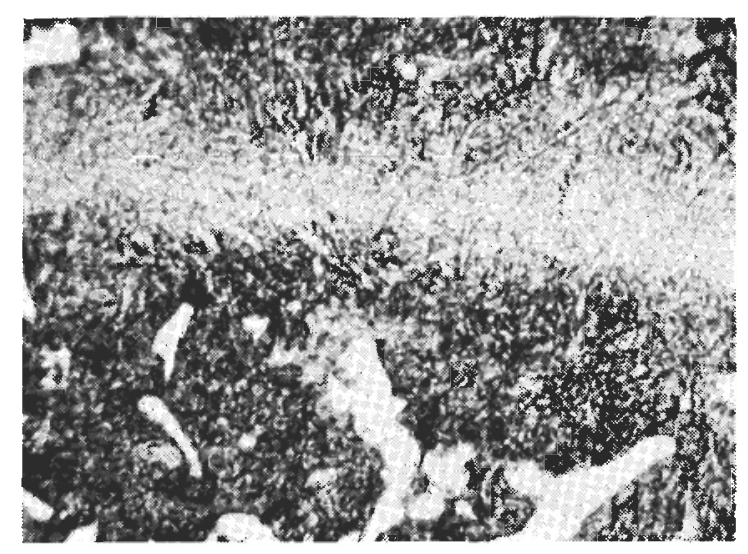


Sword 3 X 2000. Limperced bainite (?) with some grains of territe

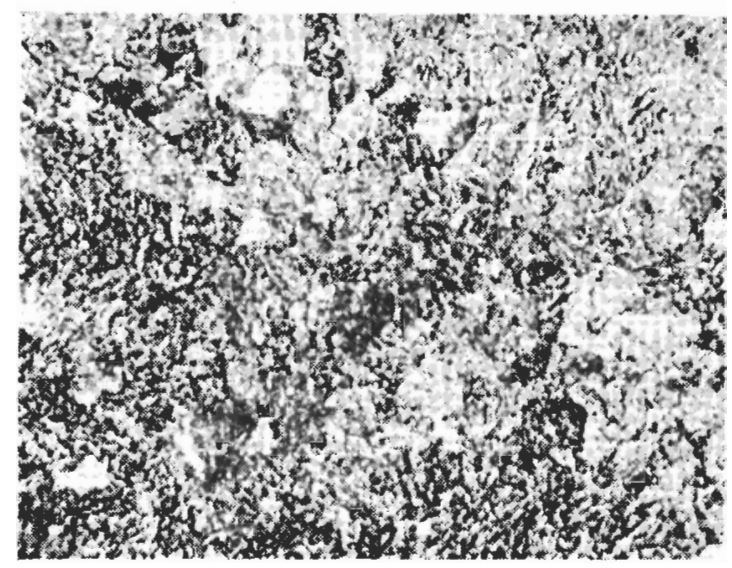




\section{SPECIMEN NO. 4 \\ STYRIAN «HAND-AND-A-HALF》 SWORD, LATE SIXTEENTH CENTURY \\ No. 17, Graz Armoury}

A fragment from the edge of the blade was mounted and examined microscopically. At low magnification, it may be seen that the section visible is a homogeneous, heat-treated steel. No ferrite grains, and only a small number of slag inclusions are visible.

At high magnification the structure may be resolved. It consists principally of tempered martensite but these are areas of an acicular structure which is probably bainite.

\section{Hardness}

Average micro hardness $=325 \mathrm{~kg} \cdot \mathrm{mm}^{-2}$

(maximum 360)

(minimum 305)

\section{Conclusions}

As far as one can tell from one fragment, this sword was made from a homogeneous steel.

The blade was then hardened by heat-treatment. The bainitic areas are possibly where the steel is of slightly lower carbon content, and so has responded differently to heat treatment. The heat-treatment probably consisted of slackquenching (not all of the steel forming martensite) followed by reheating, but without studying a full section it is not possible to be certain. 
(etched)

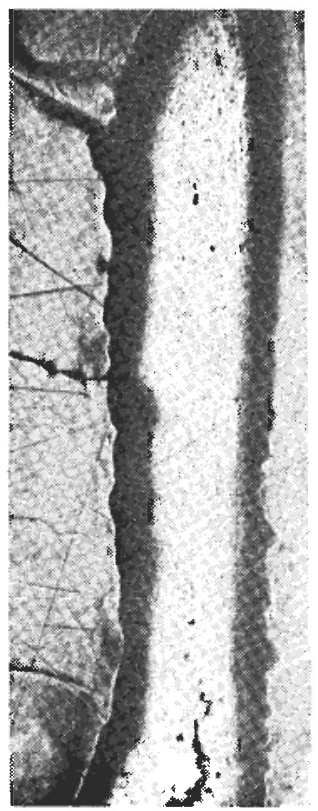

Sword 4 X 50

(unetched)

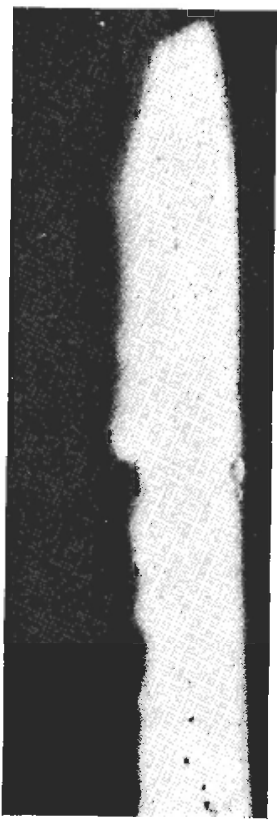

The steel is fairly homogeneous.

No ferrite visible. 


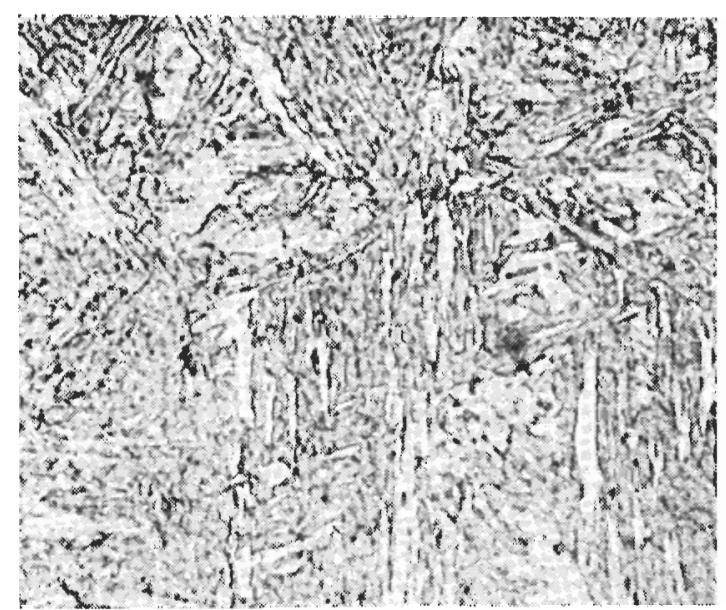

Sword 4 X 1600. Bainite

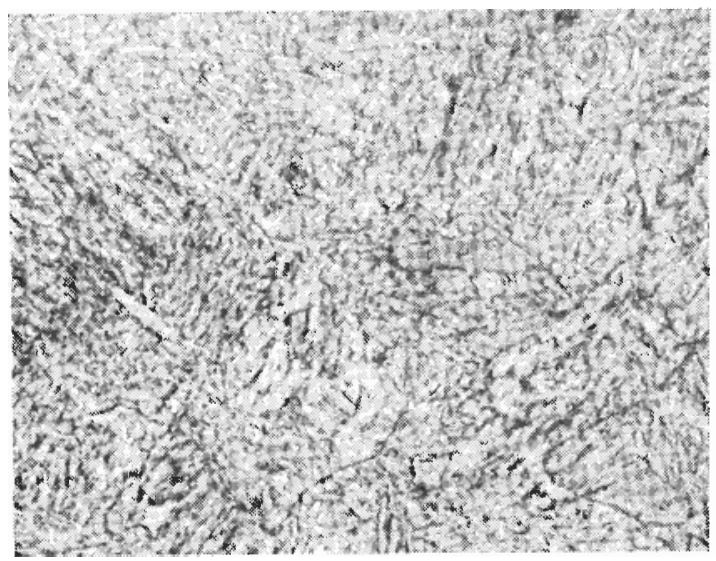


SPECIMEN NO. 5

\section{Late 16 th or early 17 th century sword (possible Spanish) (No number)}

The microstructure shows bands of light-brown- and dark-brown-etching material which merge into one arother. These bands ( 3 darker, 2 lighter) are roughly parallel to the faces of the sword and so tend to merge together near the edge.

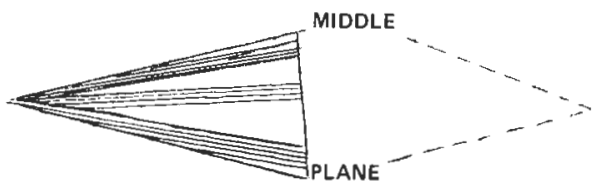

Upon examination at higher magnification, it is found that the darker areas consist mostly of a brown etching material with a little ferrite, frequently in a spiny form. The lighter areas consist of similar brown-etching areas mixed with a greater proportion of ferrite, thus producing a lighter overall appearance. This brown-etching material is irresolvable by optical microscopy and is probably bainite, although some very fine pearlite is also present.

There is no sharp division between bands, the proportion of ferrite altering smoothly. There are a moderate number of slag inclusions whose position is not noticeably dependent on the bands. Many of the inclusions appear circular, i. e. they are at right-angles to the plane of the photograph, or parallel to the longest axis of the sword.

This sword has been made by piling together one or two pieces of steel of different carbon content (or perhaps one carburised piece) and forging out into a bar whose carbon content varied from 0.3 to $0.6 \%$ as a very rough approximation.

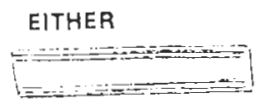

OR PERHAPS
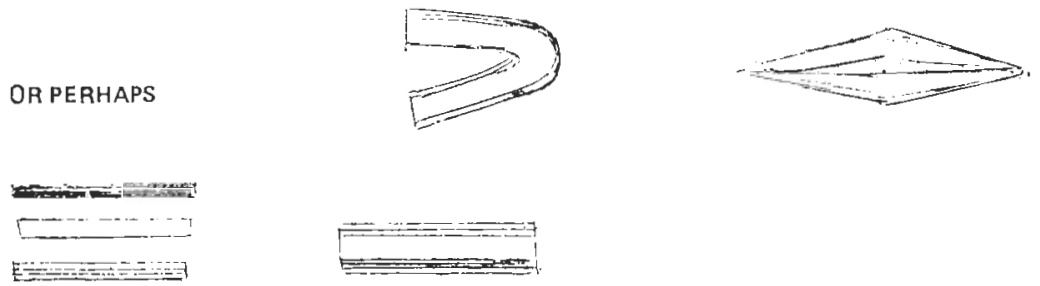

However piled, the steel sword was hardened by slack-quenching (perhaps into an oil-bath) and was not quenched-and-tempered. The reason for this was perhaps that slack-quenching is an easier process to manage, particularly without instruments.

This might well have been considered worth the price of an inferior hardness.

Average VPH (2 low-carbon areas) $=253 \mathrm{~kg} \cdot \mathrm{mm}^{-2}$

( 3 high-carbon areas) $:=437 \mathrm{~kg} \cdot \mathrm{mm}^{-2}$ 
Sword $5 \times 80$. The edge of the sword. 4.38

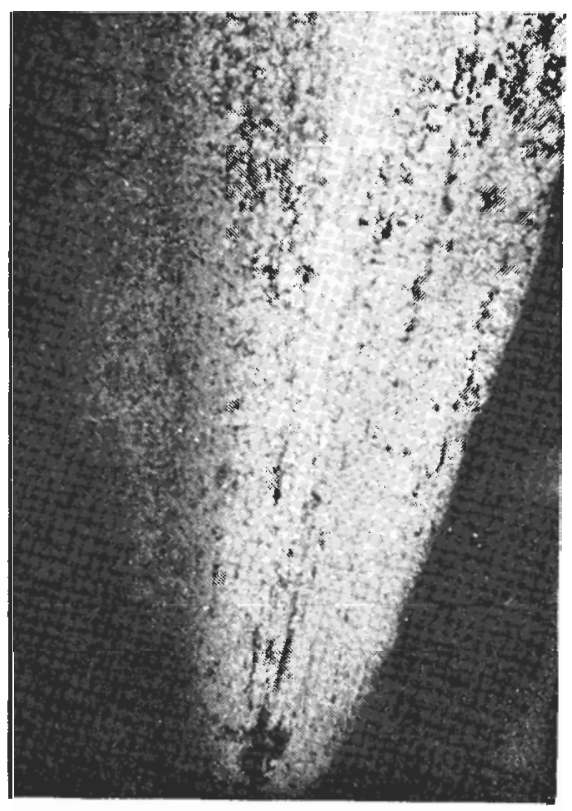


Sword $5 \times 80$. Just behind the edge of the sword. 4.32

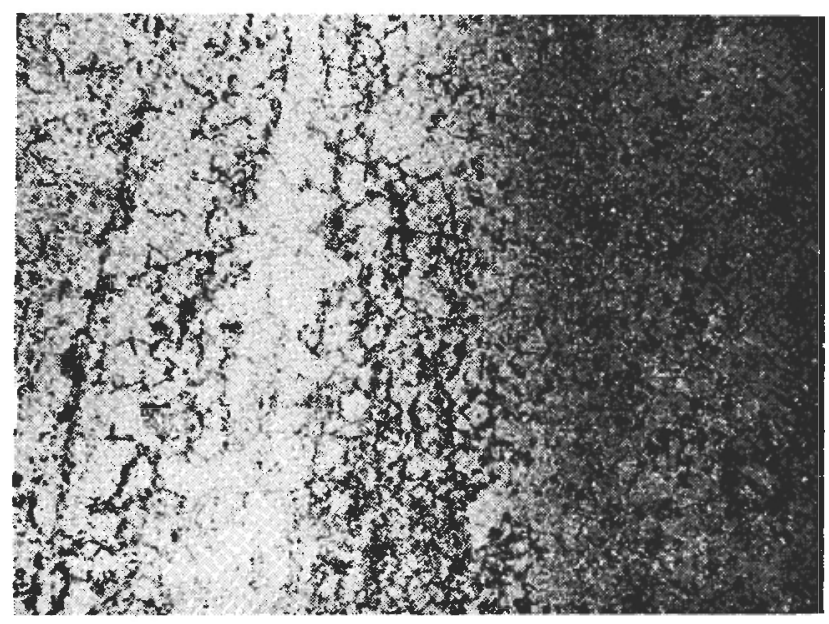

Sword $5 \times$ 80. Further away from the edge. Distinct banding of high-and low-carbon areas can be seen. The greater amount of ferrite in the lower-carbon areas makes them lighter in appearance. 4.30

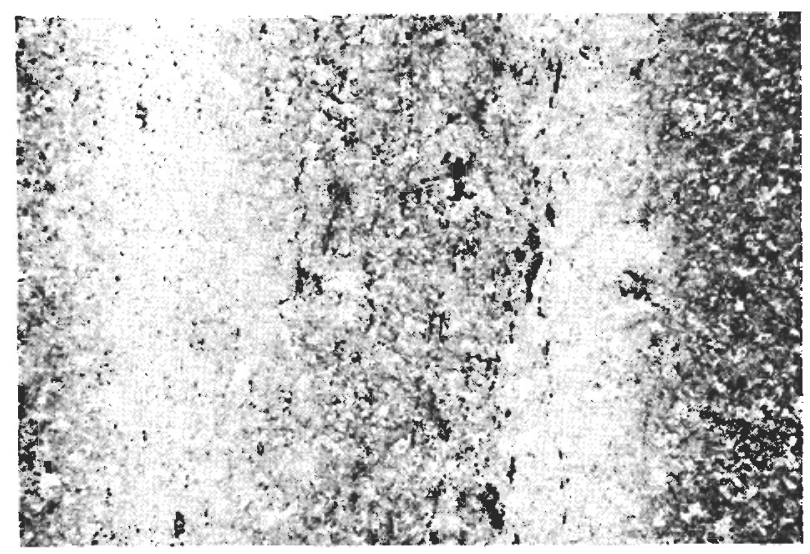




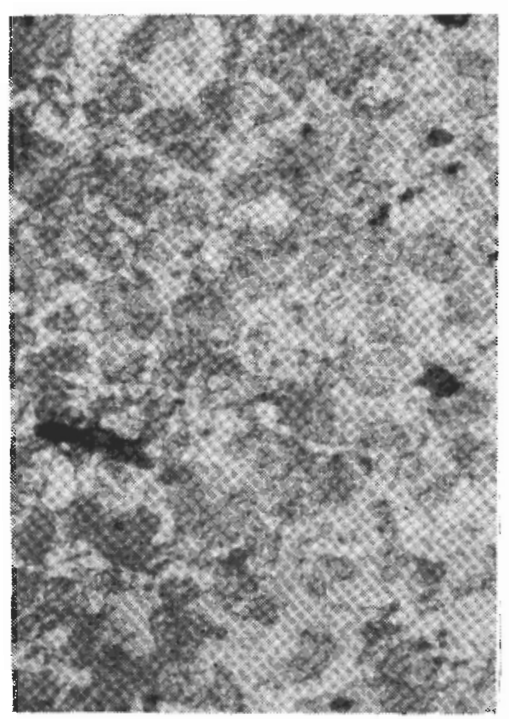

Sword 5 X 1070. Lower-carbon area. 1.5

A mixture of bainite (or perhaps fine pearlite) with a little ferrite

Sword 5 X 1070. Higher-cartorn area. 2.38

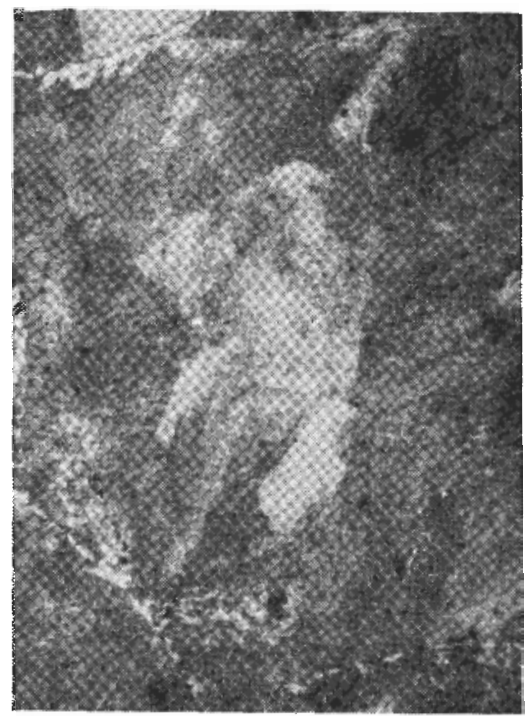




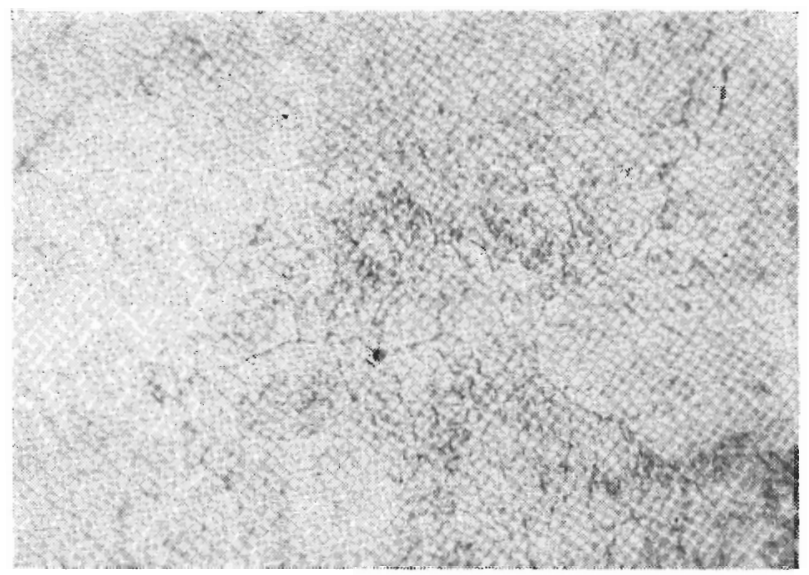

Sword $5 \times$ 1600. Bainite and increasing amounts of ferrite. 4.26

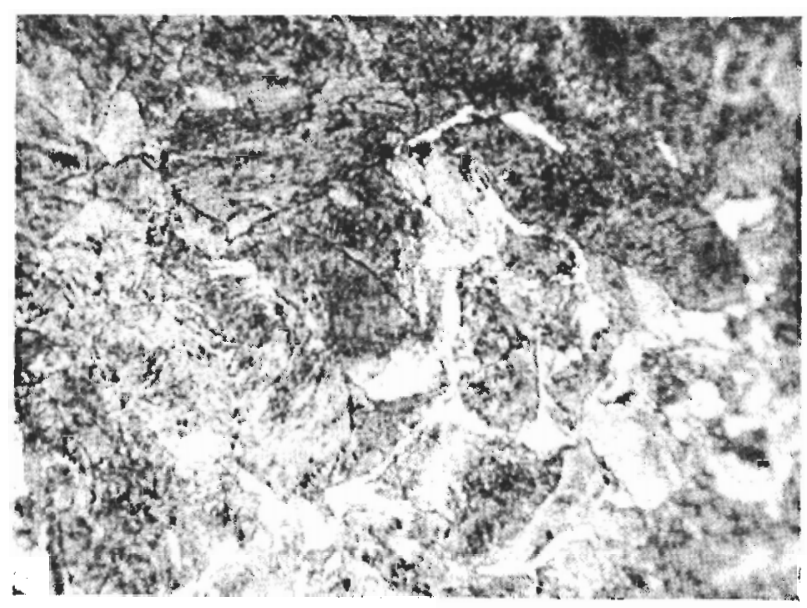


SECTION FROM A SWORD-BLADE; LATE SEVENTEENTH OR EARLY EIGHTEÉNTH

CEntury; probably German. (LAbelled specimen 6)

\section{From Swiss Arms and Armour Institute}

At low magnification, the banding in the structure of this blade is conspicuous. There is no ferrite visible, and the bands are due to layers of lighter- and darkerbrown etching material.

This material is fairly homogeneous, and the variations in colour are probably due to differences in carbon content.

At higher magnification it is found that the structure of these layers consists principally of slightly-tempered martensite, but there is another darker, feathery component present. This may be lower bainite.

\section{Hardness}

Average hardness $=441 \mathrm{~kg} \cdot \mathrm{mm}^{-2}$

\section{Conclusions}

This sword has been made by piling together several pieces of steel of different carbon content and skilfully forging them into a bar from which the sword has been shaped. Little slag has been incorporated and little carbon lost. The sword has been hardened by fully quenching (i.e. into water) and then slightly tempered by reheating.

\section{N.B.}

This is very similar to the later blade from Solingen - specimen 7 . 
(etched)

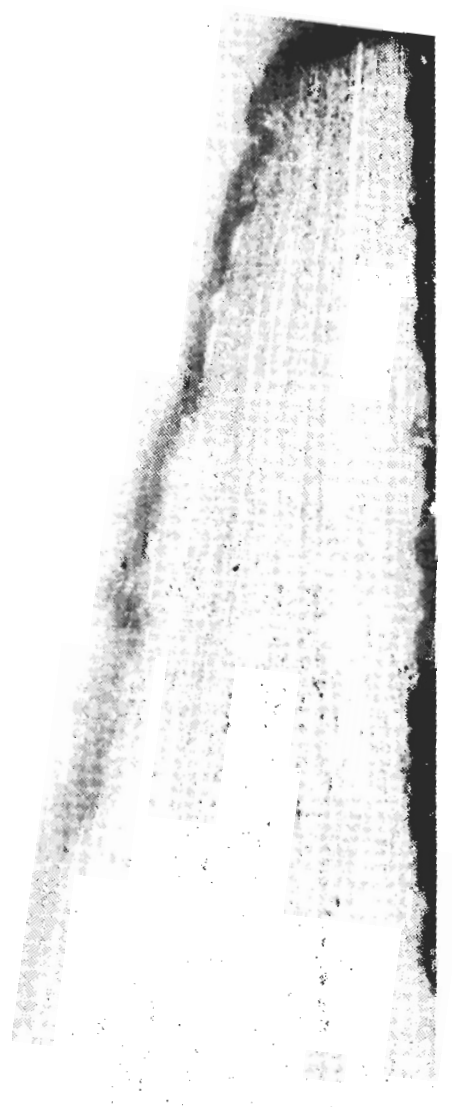

Sword $6 \times 50$

\section{(unerched)}

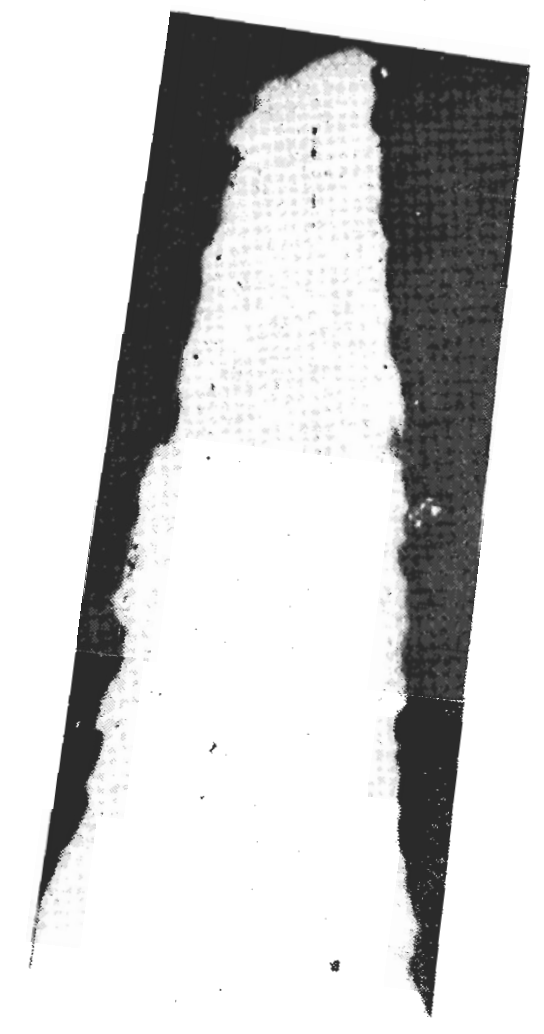


Sword 6 X 2000. Martensite and another, datker, component (possibly bainite)
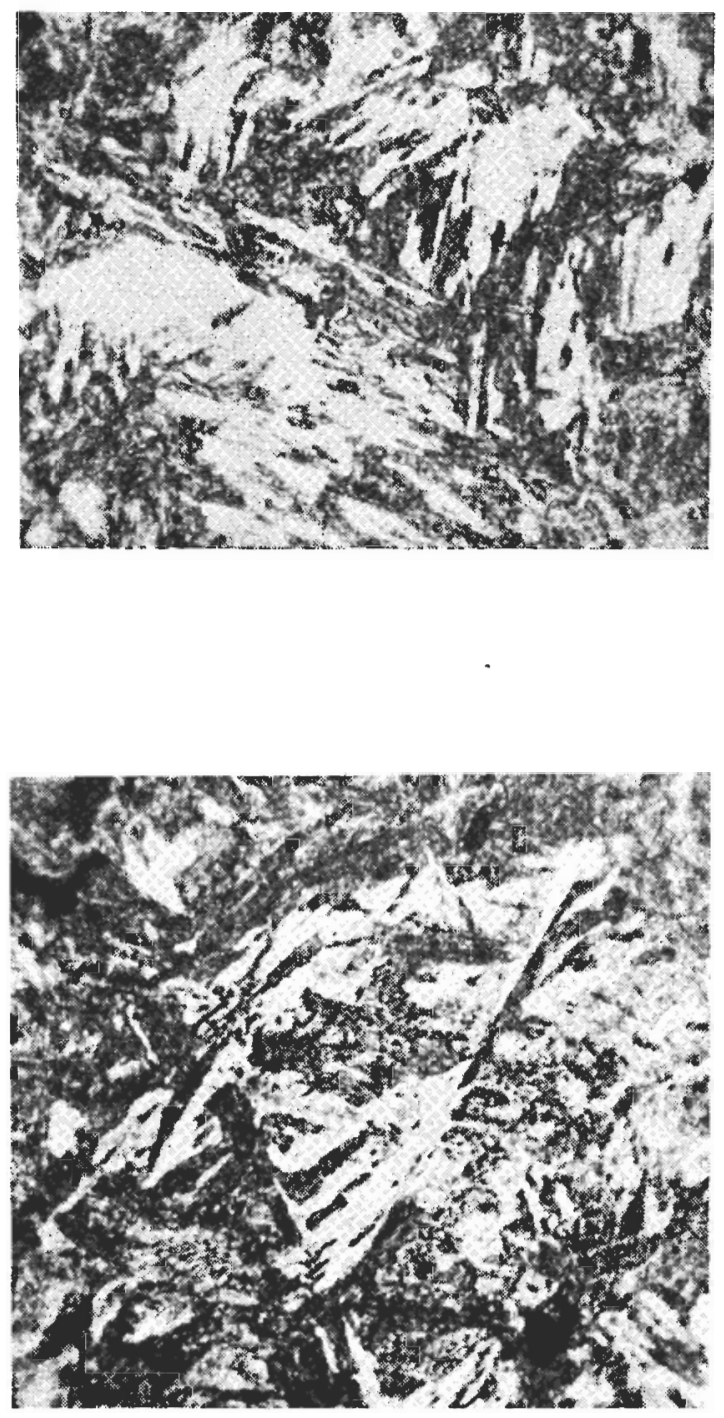


\section{(S. W. I.) SPECIMEN NO. 7}

SeCtTon from a sword-blade from Solingen, Mid-eighteEnTH CENTURy

At low magnification, the banding in the gross structure of this blade is conspicuous. However, apart from a small area near the edge where some decarburisation has taken place, there is very little ferrite visible.

The bands are due to layers of material which are light or dark-brown etching, probably due to variations in carbon content. This material is fairly homogeneous.

At higher magnification it is found to contain slightly-tempered martensite, and possibly some bainite as well probably due to variation in carbon content.

There is very little slag visible as elongated inclusions but numerous small globular ones. These are evidently sections of inclusions perpendicular to the plane of the photograph (i. e. parallel to the longest axis of the blade).

\section{Hardness}

Average $\mathrm{VPH}=472 \mathrm{~kg} \cdot \mathrm{mm}^{-2}$

\section{Conclusions}

This sword has been made by piling together several pieces of steel and skilfully forging them into a bar from which the sword has been shaped.

Little slag has been incorporated and little carbon lost. The sword has been hardened by fully quenching (i.e. into water) and then carefully tempered by reheating. 
Sword 7 X 50. A steel showing traces of piling. No ferrite is visible

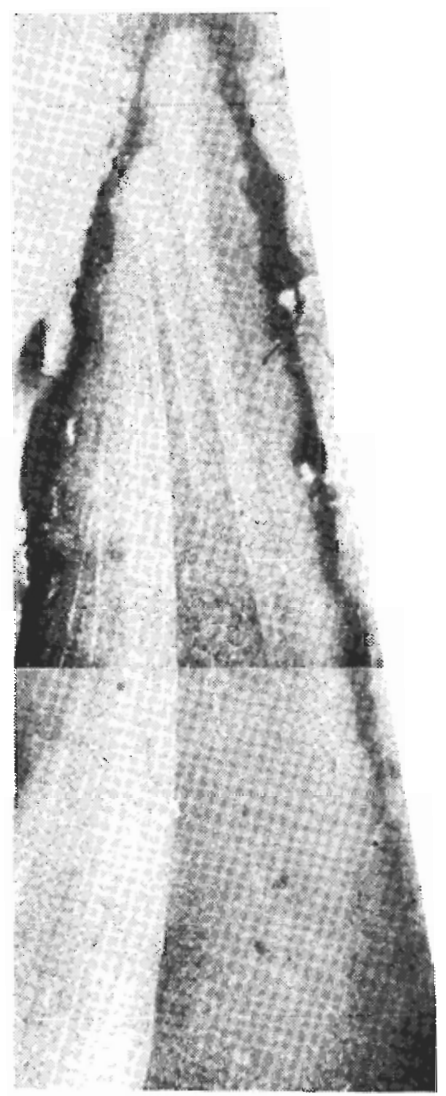


Sword $7 \mathrm{X}$ 2000. Tempered martensite, showing slag inclusions which are perpendicular to the plane of the photograph

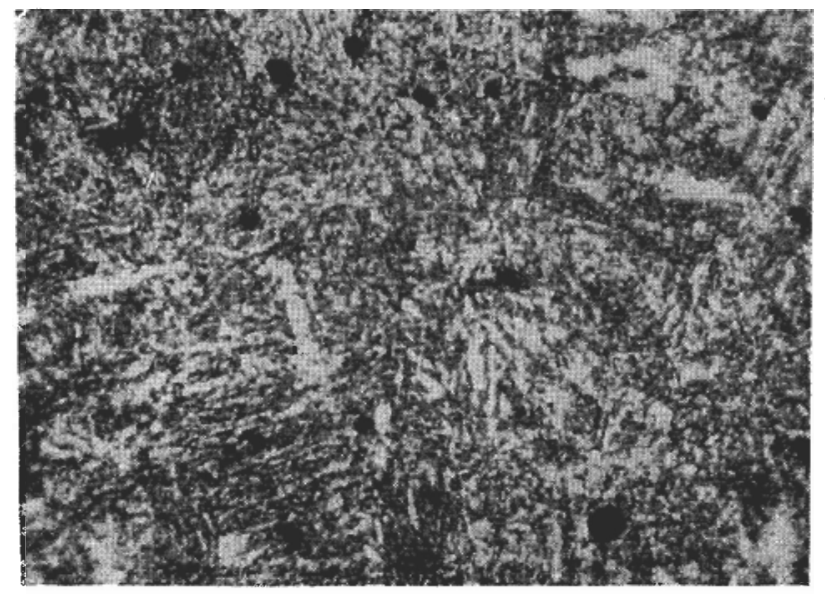

Sword 7 X 1600. Tempered martensite

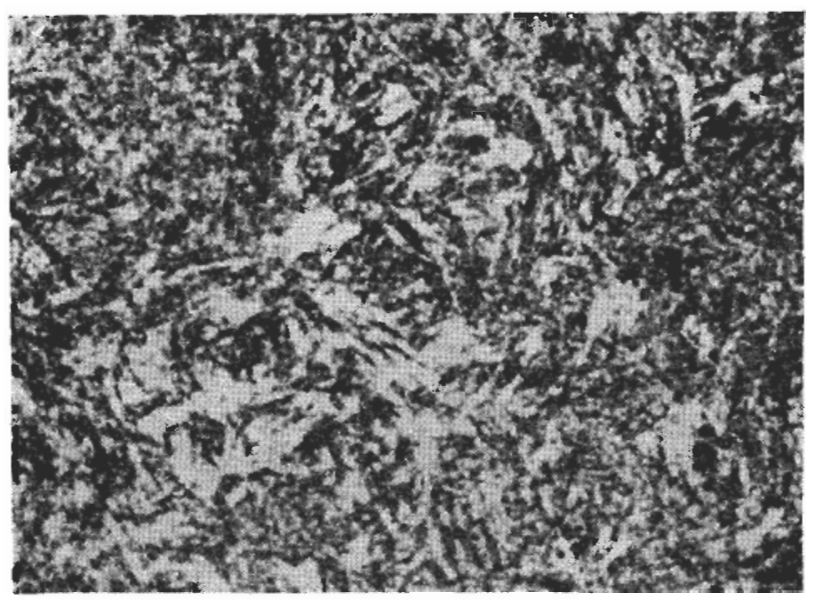

